\title{
Faktor-faktor yang Berhubungan dengan Status Karies Gigi Anak Usia Prasekolah Kabupaten Sleman Tahun 2015
}

\author{
Factors Associated with Dental Caries Status among Preschool Children in Sleman District 2015
}

Sri Utami

Program Studi Kedokteran Gigi, Fakultas Kedokteran dan Imu Kesehatan, Universitas Muhammadiyah Yogyakarta

DATA OF ARTICLE:

Received: 11 May 2017

Reviewed: 21 May 2017

Revised: 06 Jul 2017

Accepted: 12 Jul 2018

\section{*CORRESPONDENCE:}

sri.utami@umy.ac.id

DOI:

$10.18196 / \mathrm{mm} .180218$

TYPE OF ARTICLE:

Research

\begin{abstract}
Abstrak: Karies gigi anak merupakan masalah utama di negara-negara sedang berkembang. Prevalensi karies gigi anak usia 3-6 tahun di Kota Yogyakarta mencapai $84,1 \%$. Karies gigi merupakan multifactorial desease, antara lain faktor host, agent dan lingkungan mulut. Tujuan penelitian ini adalah untuk mengetahui hubungan $\mathrm{pH}$ saliva, plak gigi, frekuensi menyikat gigi dengan status karies gigi anak usia prasekolah. Jenis penelitian ini adalah observasional dengan case control study. Subyek penelitian adalah 80 anak-anak usia 4-6 tahun di TK wilayah Kabupaten Sleman. Teknik sampling yang digunakan adalah purposive sampling. Status karies gigi diukur menggunakan indeks def-s, plak gigi diukur menggunakan indeks PHP-M dan $\mathrm{pH}$ saliva diukur menggunakan $\mathrm{pH}$ digital meter, serta frekuensi menyikat gigi diukur menggunakan kuesioner. Analisis data yang digunakan adalah logistic regression. Hasil analisis multivariat menunjukkan bahwa plak gigi berhubungan dengan status karies gigi dengan $\mathrm{OR}=4,3$ dan $\mathrm{p}=0,015, \mathrm{pH}$ saliva dengan $\mathrm{OR}=6,2$ dan $\mathrm{p}=0,002$ dan frekuensi menyikat gigi dengan $\mathrm{OR}=6,5$ dan $\mathrm{p}=0,002$. Plak gigi, $\mathrm{pH}$ saliva dan frekuensi menyikat gigi merupakan faktor risiko yang berhubungan dengan status karies gigi anak usia prasekolah. Frekuensi menyikat gigi merupakan faktor risiko yang paling berperan dalam kejadian karies gigi anak usia prasekolah.
\end{abstract}

Kata kunci: : Faktor Risiko Karies; Usia Prasekolah; Indeks Def-s 


\section{PENDAHULUAN}

Karies gigi adalah penyakit mulut dengan morbiditas serta prevalensi yang sangat tinggi, tidak ada satupun daerah yang bebas dari karies. Karies menyerang semua umur, pada tingkatan status sosial ekonomi, jenis kelamin dan semua suku ataupun ras. ${ }^{1}$ Penyakit gigi mulut dapat mengurangi aktivitas pada anak sekolah, pekerja ataupun aktivitas di rumah sehingga menyebabkan seseorang kehilangan jam sekolah serta jam kerja. ${ }^{2}$ Karies gigi lebih sering diderita anak-anak dibandingkan penyakit lainnya seperti penyakit hay fever, bronkhitis kronis serta penyakit asma. ${ }^{3}$

Karies gigi pada anak-anak adalah penyakit yang multifaktorial, disebabkan oleh berbagai determinan dan faktor risiko. ${ }^{1}$ Faktor risiko tersebut meliputi lingkungan keluarga, sosial-ekonomi, budaya, pemanfaatan pelayanan kesehatan gigi, pendidikan, oral hygiene dan faktor lingkungan. ${ }^{4}$ Faktor risiko karies gigi meliputi faktor saliva, faktor diet, faktor fluoride, faktor biofilm dan plak gigi, serta fak-tor modifikasi. Kejadian karies dipengaruhi oleh oral hygiene, plak gigi akan terbentuk jika seseorang tidak menjaga kebersihan mulutnya dengan benar. ${ }^{5}$

Saliva merupakan faktor yang berperan dalam proses terjadinya karies. Parameter $\mathrm{pH}$ saliva berhubungan dengan kejadian karies gigi, $\mathrm{pH}$ saliva yang rendah berhubungan dengan tingkat kejadian ka-ries yang tinggi. Gigi yang sudah mengalami demineralisasi pada awal proses karies tidak dapat mengalami remineralisasi pada suasana $\mathrm{pH}$ saliva yang rendah atau asam. ${ }^{6}$ Studi sebelumnya banyak meneliti tentang faktor tingkat pendidikan yang dihubungkan dengan status kaies gigi anak-anak, hal tersebut sangat berbeda dengan penelitian ini karena selain faktor dari orang tua, juga meneliti faktor risiko dari anak-anak yaitu plak gigi, frekuen-si menyikat gigi dan $\mathrm{pH}$ saliva.

Tujuan penelitian ini adalah untuk melihat hubungan antara $\mathrm{pH}$ saliva, plak, frekuensi menyi-kat gigi terhadap status karies gigi anak usia prase-kolah. Hasil penelitian diharapkan bisa memberikan manfaat bagi pihak sekolah dan para orang tua terkait faktor-faktor risiko karies anak usia prasekolah, sehingga bisa dijadikan dasar penyusunan perencanaan program sekolah yang berkolaborasi dengan orang tua siswa, yang mendukung peningkatan status kesehatan gigi dan mulut para siswa.

\section{BAHAN DAN CARA}

Jenis penelitian ini adalah observasional analitik dengan desain kasus-kontrol. Jumlah subyek pe- nelitian adalah sebesar 80 anak usia 4-6 tahun, 40 anak sebagai kasus dan 40 anak sebagai kontrol. Subyek penelitian diambil dengan purposive sampling technique. Kriteria inklusi subyek meliputi siswa atau siswi TK di wilayah Kabupaten Sleman, dalam keadaan sehat dan orangtua bersedia men-jadi responden dan menandatangani informed con-sent, mengijinkan anak nya untuk diperiksa dan seluruh gigi anak merupakan gigi desidui. Kriteria eksklusi antara lain pernah dilakukan multiple extraction (lebih dari 4 gigi).

Instrumen yang digunakan adalah indek def-s dan indek plak O'Leary, untuk mengukur status karies gigi dan plak. Pengukuran indek def-s dan indek O'Leary dilakukan oleh 2 orang examiner. Kalibrasi antar examiner dilakukan dengan uji Kappa. Nilai koefisien Kappa pengukuran indeks def-s dan indek plak adalah 100\% ( $p=0,00)$ dan 78,9\% ( $p=0,001)$. Berdasarkan nilai tersebut dapat dinyatakan bahwa persepsi 2 examiner dalam mengukur indeks def-s dan indeks plak adalah sama.?

Hasil pengukuran indeks dmf-s merupakan jumlah permukaan gigi anak yang karies, ditumpat karena karies dan indikasi cabut karena karies. Hasil pengukuran indeks plak O'Leary merupakan persentase akumulasi plak pada semua permukaan gigi yang diperiksa. Pengukuran $\mathrm{pH}$ saliva dilakukan dengan teknik unstimulated, dengan melakukan sikat gigi 1 jam sebelum pengambilan saliva. Alat ukur $\mathrm{pH}$ saliva menggunakan digital $\mathrm{pH}$ meter (Hanna). Variabel frekuensi menyikat gigi anak diukur menggunakan kuesioner yang diisi oleh orangtua anak. Skala data variabel pada penelitian adalah kategorik, sehingga analisis yang digunakan adalah uji regresi logistik dengan menghitung nilai Odds Ratio (OR).

\section{HASIL}

Berdasarkan Tabel 1. dapat dilihat bahwa jumlah subyek penelitian yang terbanyak adalah laki-laki, yaitu 43 (58,75\%), 22 kasus dan 21 kontrol. Umur subyek penelitian terbanyak adalah pada umur 5 tahun (50\%).

Berdasarkan Tabel 2. dapat dilihat bahwa hasil analisis uji korelasi Spearman menunjukkan bahwa faktor plak gigi $(\mathrm{OR}=2,913, p=0,014), \mathrm{pH}$ saliva $(\mathrm{OR}=2,217, \mathrm{p}=0,003)$ dan frekuensi menyikat gigi $(\mathrm{OR}=3,500, p=0,007)$ berhubungan dengan status karies gigi anak usia prasekolah.

Berdasarkan Tabel 3. dapat dilihat bahwa hasil analisis uji regresi logistik menunjukkan bahwa faktor plak gigi $(\mathrm{OR}=4,3, p=0,015), \mathrm{pH}$ saliva $(\mathrm{OR}=6,2$, $p=0,002)$ dan frekuensi menyikat gigi ( $O R=6,5$, $p=0,002$ ) berhubungan dengan status karies gigi anak usia prasekolah. 
Tabel 1. Karakteristik Responden Berdasarkan Jenis Kelamin dan Umur

\begin{tabular}{|c|c|c|c|c|c|c|}
\hline \multirow{2}{*}{ Karakteristik } & \multicolumn{2}{|c|}{ Kasus } & \multicolumn{2}{|c|}{ Kontrol } & \multicolumn{2}{|c|}{ Jumah } \\
\hline & $\mathrm{n}$ & $\%$ & $\mathrm{n}$ & $\%$ & $\mathbf{n}$ & $\%$ \\
\hline \multicolumn{7}{|l|}{ Jenis Kelamin } \\
\hline Laki-laki & 22 & 54,17 & 21 & 53,11 & 43 & 58,75 \\
\hline Perempuan & 18 & 45,83 & 19 & 46,89 & 37 & 46,25 \\
\hline Jumlah & 40 & 100 & 40 & 100 & 80 & 100 \\
\hline \multicolumn{7}{|l|}{ Umur } \\
\hline 4 tahun & 3 & 7,50 & 5 & 12,50 & 8 & 10,00 \\
\hline 5 tahun & 23 & 57,50 & 17 & 42,50 & 40 & 50,00 \\
\hline 6 tahun & 14 & 35,00 & 18 & 45,00 & 32 & 40,00 \\
\hline Jumlah & 40 & 100 & 40 & 100 & 80 & 100 \\
\hline
\end{tabular}

Tabel 2. Hasil Uji Korelasi Spearman

\begin{tabular}{|c|c|c|c|c|c|c|c|c|}
\hline \multirow{2}{*}{ Variabel } & \multicolumn{2}{|c|}{ Kasus } & \multicolumn{2}{|c|}{ Kontrol } & \multicolumn{2}{|c|}{ Total } & \multirow{2}{*}{ OR } & \multirow{2}{*}{$p$ value } \\
\hline & $\mathrm{n}$ & $\%$ & $\mathrm{n}$ & $\%$ & $\mathrm{n}$ & $\%$ & & \\
\hline \multicolumn{9}{|l|}{ Plak gigi } \\
\hline Rendah & 11 & 27,50 & 21 & 52,50 & 32 & 40,00 & \multirow{2}{*}{2,913} & \multirow{2}{*}{0,014} \\
\hline Tinggi & 29 & 72,50 & 19 & 47,50 & 48 & 60,00 & & \\
\hline \multicolumn{9}{|l|}{$\mathrm{pH}$ saliva } \\
\hline Rendah & 17 & 42,50 & 10 & 25,00 & 27 & 33,75 & \multirow{2}{*}{2,217} & \multirow{2}{*}{0,003} \\
\hline Tinggi & 23 & 57,50 & 30 & 75,00 & 53 & 66,25 & & \\
\hline \multicolumn{9}{|c|}{ Frekuensi sikat gigi } \\
\hline Jarang & 28 & 70,00 & 16 & 40,00 & 44 & 55,00 & \multirow{2}{*}{3,500} & \multirow{2}{*}{0,007} \\
\hline Sering & 12 & 30,00 & 24 & 60,00 & 36 & 45,00 & & \\
\hline
\end{tabular}

Tabel 3. Hasil Uji Regresi Logistik

\begin{tabular}{lccccc}
\hline \multicolumn{1}{c}{ Variabel } & B & S.E. & OR & Sig. & 95 \% CI \\
\hline Plak gigi & 1,450 & 0,595 & 4,3 & 0,015 & $1,328-13,697$ \\
pH saliva & 1,822 & 0,601 & 6,2 & 0,002 & $1,905-20,089$ \\
Frekuensi sikat gigi & 1,871 & 0,618 & 6,5 & 0,002 & $1,933-21,783$ \\
\hline
\end{tabular}

\section{DISKUSI}

Hasil analisis deskriptif menunjukkan bahwa kejadian karies gigi cenderung lebih banyak pada anak laki-laki dibanding anak perempuan dan paling banyak pada usia 5 tahun. Hasil uji bivariat dan multivariat menunjukkan bahwa faktor plak gigi, $\mathrm{pH}$ saliva dan frekuensi menyikat gigi berhubungan dan merupkan faktor risiko terhadap karies gigi anak.

Odds Ratio untuk faktor plak gigi adalah sebesar 4,3 sehingga dapat dinyatakan bahwa anak dengan indek plak yang tinggi mempunyai risiko 4,3 kali lebih besar untuk menderita karies gigi dibandingkan anak-anak dengan indek plak yang rendah. Tingkat kebersihan mulut serta penumpukan plak merupakan faktor risiko kejadian karies gigi anak usia prasekolah. Lingkungan yang cocok untuk bak-teri kariogenik berkembang biak adalah pada saat meningkatnya kontak antara plak dengan substrat. ${ }^{8}$ Kontrol diet dapat mengurangi kontak antara substrat dengan plak, sehingga bakteri plak tidak mampu melakukan fermentasi. ${ }^{9}$ lbu berperan sangat besar di dalam mencegah terjadinya penum-pukan plak dan terjadinya karies gigi pada anak. ${ }^{10}$ Beberapa penelitian mengemukakan bahwa terda-pat hubungan antara indek plak dengan tingkat keparahan karies gigi anak.11

Nilai OR faktor $\mathrm{pH}$ saliva adalah sebesar 6,2 sehingga dapat dinyatakan bahwa anak-anak dengan $\mathrm{pH}$ saliva asam mempunyai risiko 6,2 kali lebih besar untuk menderita karies gigi dibandingkan anak-anak dengan $\mathrm{pH}$ saliva basa. Aliran saliva yang berkurang menyebabkan bakteri kariogenik berkembang biak dengan cepat. Parameter saliva seperti flow rate, viskositas, buffer dan $\mathrm{pH}$ saliva berhubungan dengan kejadian karies gigi, $\mathrm{pH}$ saliva yang rendah berhubungan dengan tingkat kejadian karies yang tinggi. Gigi yang sudah mengalami demineralisasi pada awal proses karies tidak dapat mengalami remineralisasi pada suasana $\mathrm{pH}$ saliva yang rendah atau asam. ${ }^{7}$

Nilai OR untuk faktor frekuensi menyikat gigi adalah sebesar 6,5 sehingga dapat dinyatakan bahwa anak-anak yang jarang menyikat gigi mempu-nyai risiko 6,5 kali lebih besar untuk menderita karies dibandingkan anak-anak yang sering menyikat gigi. 
Status kebersihan gigi pada anak-anak umumnya lebih buruk dibandingkan dengan status kesehatan gigi orang dewasa, karena anak-anak sangat suka makan makanan manis tetapi kesa-daran untuk menjaga dan memelihara kebersihan mulutnya sangat kurang. Cara dan frekuensi menyi-kat gigi yang tidak tepat, serta frekuensi konsumsi karbohidrat adalah faktor risiko karies gigi anak. ${ }^{12}$

Parental coping skill serta self efficacy yang sejalan dengan kondisi sehat merupakan kunci yang berpengaruh terhadap status kesehatan dalam keluarga, terutama pada anak-anak. ${ }^{13}$ Perilaku ibu dalam membimbing dan mengajarkan kebiasaan menyikat gigi pada anak-anak merupakan hal yang sangat penting, yang berhubungan dengan keja-dian karies pada anak usia prasekolah. ${ }^{14}$ Kegiatan menyikat gigi merupakan kegiatan motoric yang dapat diterapka kepada anak, tetapi peran orang tua masih sangat besar di dalam menentukan keberhasilan dalam pemeliharaan kesehatan gigi anak. $^{10}$

\section{SIMPULAN}

Plak gigi, pH saliva dan frekuensi menyikat gigi merupakan faktor risiko kejadian karies gigi anak. Frekuensi menyikat gigi adalah faktor risiko yang paling berperan dalam kejadian karies gigi anak usia prasekolah. Kontrol diet dan menyikat gigi dengan benar adalah salah satu cara pencegahan karies gigi pada anak. Peran orang tua sangat penting dalam membentuk perilaku kesehatan gigi mulut pada anak-anak. Perlunya program promotif dan preventif untuk menurunkan prevalensi ECC dan meningkatkan status kesehatan gigi dan mulut anak, seperti kegiatan sikat gigi bersama dengan aplikasi plak marker; yang melibatkan orang tua siswa.

\section{DAFTAR PUSTAKA}

1. Moses JM, Rangeeth BN dan Gurunathan D. Prevalence of Dental Caries, Socio-Economic Status and Treatment Needs among 5 to 15 Year Old School Going Children of Chidambaran. J Clin Diagnostic Res, 2011; 5 (1): 146-151.
2. Petersen PE, Bourgeois D, Ogawa H, EstupinanDay S dan Ndiaye C. The Global Burden of Oral Disease and Risk to Oral Health. Bulletin of The World Health Organization, 2005; 83: 661-669.

3. Depoala DP, Clakrson JJ, Gluch JI, Roach K dan Wang X. Update on Early Childhood Caries. The Colgate Oral Care Report, 2010; 20 (2): 1-3.

4. Borutta A, Wagner M dan Kneist S. Early Childhood Caries: A Multi-Factorial Disease. OHDMBSC, 2010; 9 (1): 32-38.

5. Pretty IA. Caries Detection and Diagnosis: Novel Technologies. Journal of Dentistry, 2006; 34: 727 739.

6. Dawes C. What Is Tha Critical pH and Why Does A Tooth Dissolve in Acid?. J Cand Dent Assoc, 2003; 69 (11): 722-724.

7. Murti, B., (1997), Prinsip dan Metode Riset Epidemiologi, Gadjah Mada University Press.

8. Zafar S, Harnekar SY dan Siddiqi A. Early Childhood Caries: Etiology, Clinical Considerations, Consequences and Management. International Dentistry SA, 2006; 11 (4): 24-36.

9. Marsh PD. Dental Plaque as A Biofilm: The Significance of $\mathrm{pH}$ in Health and Caries. Continuing Education, 2009; 30 (2): 76-87.

10. Riyanti E. Pengenalan dan Perawatan Kesehatan Gigi Anak Sejak Dini. Seminar Sehari Kesehatan Psikologi Anak. 2005.

11. Shimizu K, Igarashi K dan Takahashi N. Chairside Evaluation of $\mathrm{pH}$ Lowering Activity and Lactic Acid Production of Dental Plaque: Correlation with Caries Experience and Incidence in Preschool Children. Quintessence International, 2008; 30 (2): 151-158.

12. Schroth RJ, Brothwell DJ dan Moffatt MEK. Caregiver Knowledge and Attitudes of Preschool Oral Health and Early Childhood Caries (ECC). Int J Circumpolar Health, 2007; 66 (2): 153-167.

13. Finlayson TL, Siefert K, Ismail AL dan Sohn W. Maternal Self Efficacy and 1-5 Year Old Children's Brushing Habits. Community Dent Oral Epidemiol, 2007; 35 (4): 272-281.

14. Owen SA, Gansky SA, Platt LJ, Weintraub JA, Soobader MJ, Bramlett MD, et al. Influences on Children's Oral Health: A Conceptual Model. Pediatrics, 2007; 120 (3): 510-520. 